Albright's hereditary osteodystrophyを伴つた原発性 副甲状腺機能六進症（腺腫）の 1 症例

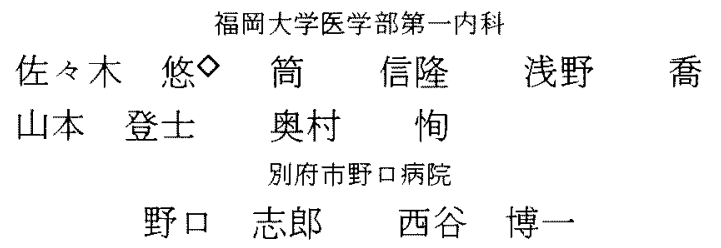

\title{
A CASE OF PRIMARY HYPERPARATHYROIDISM (ADENOMA) ASSOCIATED WITH ALBRIGHT'S HEREDITARY OSTEODYSTROPHY
}

\author{
Haruka SASAKI, MD, Nobutaka TsuTsu, MD, Takashi ASANO, MD, \\ Takashi Yamamoto, MD and Makoto OKumuRA, MD \\ The First Department of Internal Medicine, Fukuoka \\ University School of Medicine, Fukuoka \\ Shiro NoGUCHI, MD and Hirokazu NishitanI, MD \\ Noguchi Hospital, Beppu
}

\begin{abstract}
概要 本邦第 1 例目と考えられるAlbright's hereditary osteodystrophy (AHOと略) を合併し た原発性副甲状腺機能え進症（腺腫）(PHと略）の1例を経験したので，その概要を報告する。 症例は22才，女性。断続的な上腹部痛，悪心を主訴に受診，消化管透視には異常なく，Albright 徵候に加之，血清Ca高值，血清 $\mathrm{P}$ 正常下限，血清alk-P-aseの増加を指摘され，精查のため入院 した，理学的所見にて短躯・短頸，円形顔貌，知能障害，第IV中手，中足骨の短縮を認め，家 系内にも類似の身体所見を有するものが 2 例存在し家族内発症が推定された。血中 $\mathrm{N} ， \mathrm{C}$ 末端 iPTHの高値，E11sworth-Howard試験にて偽性副甲状腺機能低下症II型（Drezner）に相当与 る反応を認めたが，骨性alk-P-ase増加，副腎皮質ホルモン負荷に抵抗性の高Ca血症の持続，急 速Ca負荷試験の成績に加点て，他に高Ca血症をきたす疾患を認好得ないことより $\mathrm{PH}$ 診断， 手術により単発性腺腫を確認した。赤血球膜 $\mathrm{N}$ 蛋白活性, 染色体核型, 血中 $1,25(\mathrm{OH})_{2}$ ビタミ ン $\mathrm{D}_{3}$ には異常を認めなかつた。術後，血清Caおよびalk·P-ase活性の低下，血清 Pの上昇ととも K，Ellsworth-Howard試験，急速Ca負荷試験の正常化，dbc-AMP負荷にてP再吸収率（\% TRP) の低下が認められ，標的器管のPTH receptorkは異常のないことが確認された。本例 はBronskyの言う“pseudo-pseudohypohyperparathyroidism”に該当するきわめてむれな症例 と考克られ，AHOと副甲状腺疾患の関連性を娭討する上で, 示唆に富を症例と考光られた。
\end{abstract}

\section{I、はじめに}

Albright遗伝性骨形成異常症 (Albright's hereditary osteodystrophy, AHOと略) はAlbright

〔昭和58年11月21日受稿〕
ら によよつて報告されたpseudohypoparathyroid ism (PHP L略) およびpseudo-pseudohypopa rathyroidism (PPHP之略) ${ }^{2}$ 亿伴う遺伝性の身体 骨格奇形を指すとされ，従来上り低身長，円形顔 貌, 肥満, 知能障害, 中手骨, 中足骨の短縮, 皮 
下石灰化などがその特徴として上げられてい る3).さらにPHPは末梢標的細胞の副甲状腺ホル モン (PTH) に対する不応性に基づく受容体異常 症の代表として注目され，ホルモン作用機構の解 明と共に，その病態に関しても新しい知見や，非 定型例の報告が集積されている374)99. 史た最近で は, hormone-adenylate cyclase系の障害に基づく $\mathrm{N}$ 蛋白欠損をも含めた広範なreceptor障害の可能 性も示唆されるなど516)，その疾患概念の变遷と共 に，現在なお多くの問題点を有した疾患である。

著者らは, AHOに特徵的身体所見に加兄, 外因 性PTHに対して, Dreznerら ${ }^{7)}$ のPHP II型に相当 する反応を示しながらも, primary hyperparathyroidism ( $\mathrm{PH}$ と略) の血液生化学所見を呈し, 手術によつて副甲状腺腺腫を確認し得た症例を経 験した。かかる例は文献上, 1970年, Bronsky ${ }^{8}$ が 新しいclinical entityのもとに“pseudo-pseudohypohyperparathyroidism”として報告した 1 例を 認めるにすぎず,極めてまれな症例と考えられる。 このよらな両者の合併は偶然の結果とも考光られ るが, PHPとAHOとの関連性, あるいは副甲状腺 疾患に拈けるterminologyを検討する上で示唆に 富む症例と考学られるので，若干の考察を加学， その概要を報告する。

\section{II. 症例および方法, 成績}

患者：22才, 女性, 無職.

主訴：腹痛, 悪心.

既往歴・生活歴：胎生期に異常なく, 満期安 産 $(2800 \mathrm{~g})$, 生来健康. 16才初潮, テタ二-. 㾏挛 発作の既往もない私立高校を中下の成績で卒業. 職は長期に続かず転々としている。

家族歴 (Fig 1)：父方祖母 (76才子宮癌死亡) 扣よび叔母に低身長, 肥満, Albright徵候が認めら れた。父母, 同胞は低身長なるも, 知能正常, 㾏 挛発作や精神疾患は認めず, 血清Ca, P, iPTH值 はいずれも正常であつた。

現病歴：昭和 52 年, 9 月頃上り, 特に誘因の ない心窩部から腹部にかけての疼痛, 時に悪心を 認め, 某病院受診。消化管透視に異常を認めず。 便秘に伴つたものとされたが, Albright徵候に加

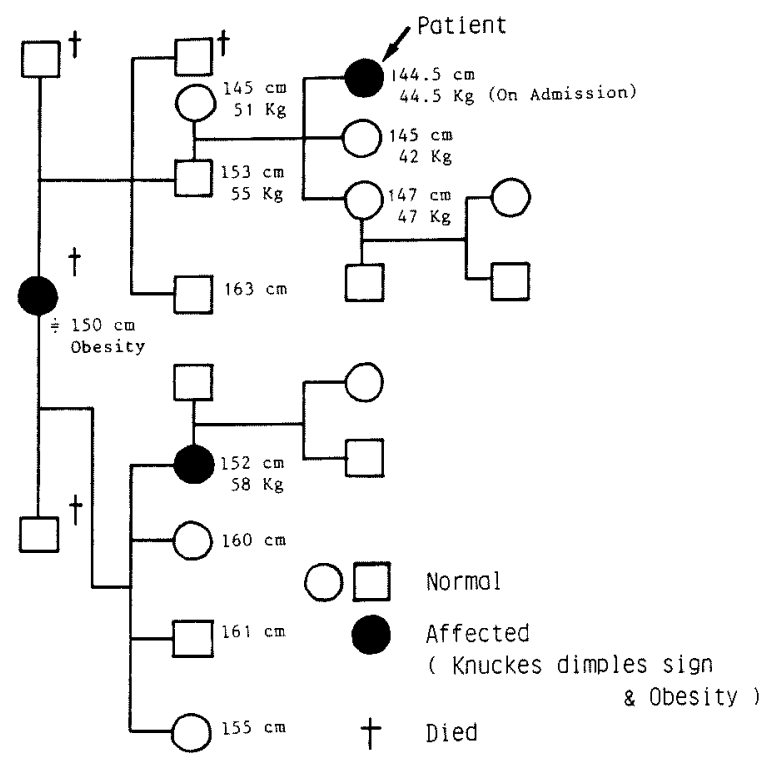

Fig 1. Pedigree of family.

之, 血清Ca高値, 血清alk-P-aseの増加を指摘さ れ, 翋年 1 月, 精査のため, 福岡大学第一内科に 入院した。

入院時現症：身長 $144.5 \mathrm{~cm}(-1.8 \mathrm{SD})$, 体重 $44.5 \mathrm{~kg}$, 意識清明, 中等度の知能低下が疑われた。 身体的特徵として短躯短頸, 円形顔貌および両側 第IV手・足指の短縮 (Fig 2A，B）を認めたが，外 反肘なく二次性徵発現は正常であつた（Fig 3). また白内障は認めず，歯牙にも特別な所見なく， 皮下結節も認めなかつた。血王 $120 / 60 \mathrm{mmHg}$ ，心 胸・腹部，前䅡部に腫瘤などの異常所見なく, Trousseau, Chvostek徵候も陰性であつた。

一般および内分泌検査成績（表 1，2）：

腎機能に異常なく, DIPにて腎・尿管結石を示唆 する所見はなかつた。また頭部CT，上下肢骨 X線 検査にて基底核石灰化，皮下石灰沈着，骨膜下吸 収像, 骨軟化症, 線維性骨炎などを示す所見は認 めなかつたが，第IV中手・中足骨短縮（Fig 2）を 認めた。染色体核型46XX. 这波検查にて発作波は ないが， $\alpha$ 波が緩徐でorganificationの低下が示唆 され，WAIS式知能検查にて言語性IQ 60以下. 動 作性IQ 60であつた。 また消化管透視では局在病 变を示唆する所見は認めなかつた。 

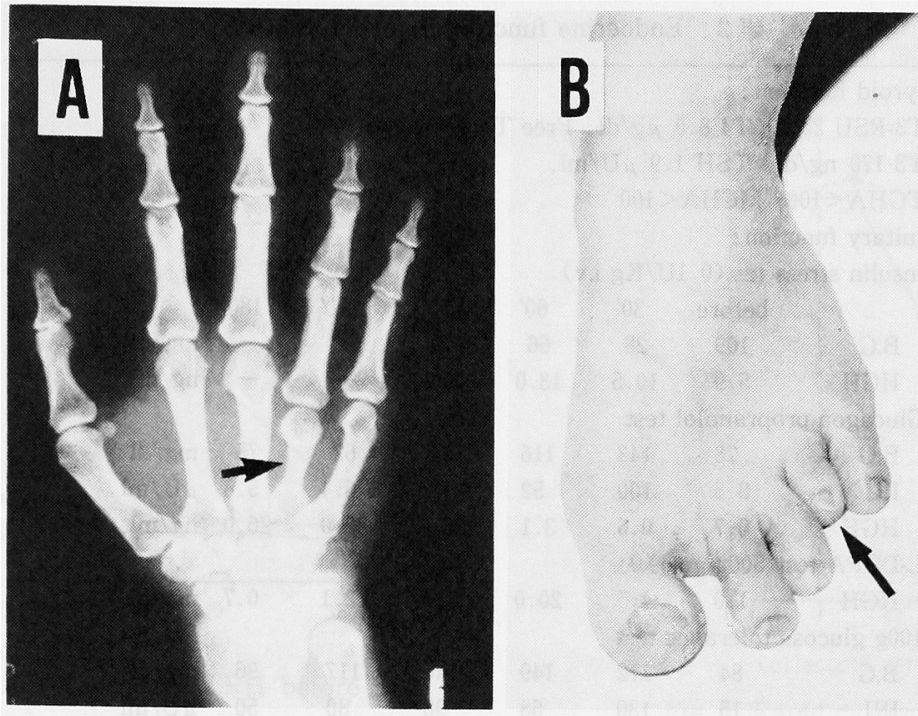

Fig 2. X-ray views of hand (A) and photography of foot (B) demonstrating the shortning of the fourth metacarpal and metatarsal.

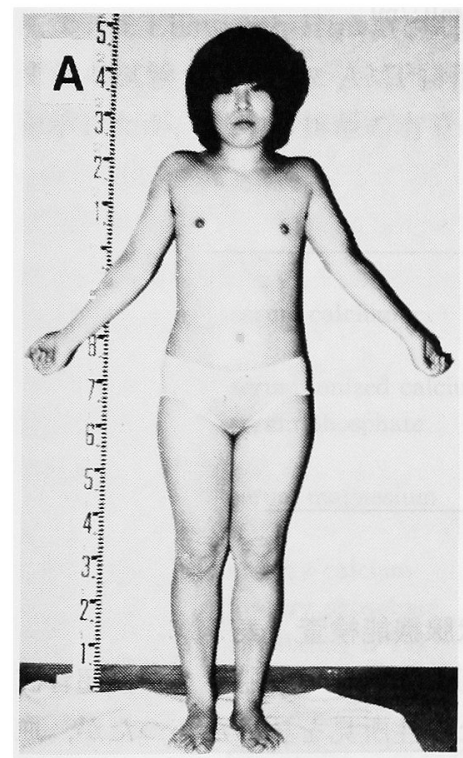

B

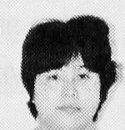

Fig 3. Photograph of propositus before (A) and after surgery (B).

副甲状腺以外の内分泌検査（表 2）では特記す べき異常所見を認めなかつたが, $\mathrm{T}_{4}, \mathrm{~T}_{3}, \mathrm{~T}_{3}-\mathrm{RUS}$, TSHいずれも正常範囲にもかかわらず，TRH負 荷に対するTSH反応は不良であつた（Fig 4）. 術前後に各種副甲状腺機能検査を施行した。血
表 1. Laboratory data on first admission.

\begin{tabular}{|c|c|c|}
\hline $\begin{array}{l}\mathrm{RBC} \\
\mathrm{Hb} \\
\mathrm{WBC}\end{array}$ & $\begin{array}{c}397 \times 10^{4} / \mathrm{mm}^{3} \\
11.6 \mathrm{~g} / \mathrm{dl} \\
5200 / \mathrm{mm}^{3}\end{array}$ & $\begin{array}{c}\text { T.Protein } 6.49 \mathrm{~g} / \mathrm{dl} \\
\text { alubumin } 4.45 \mathrm{~g} / \mathrm{dl}\end{array}$ \\
\hline Analysis & 11. p & $77 \mathrm{mg} / \mathrm{dl}$ \\
\hline $\begin{array}{l}\text { Urinalysis } \\
\text { protein }\end{array}$ & $(-)$ & $($ ALP III $\uparrow)$ \\
\hline suger & $(-)$ & 13 Karman U \\
\hline urobilinoger & $\mathrm{N}$ & 11 Karman \\
\hline acetone & $(-)$ & $302 \mathrm{IU} / \mathrm{l}$ \\
\hline sediment & u.p & $161 \mathrm{GR} \cdot \mathrm{U}$ \\
\hline serum $\mathrm{Na}$ & $140-144 \mathrm{mEq} / l$ & $\gamma$-GTP \\
\hline serum $\mathrm{K}$ & $4.1-4.5 \mathrm{mEq} / l$ & Hbs Ag \\
\hline serum $\mathrm{Cl}$ & $101-111 \mathrm{mEq} / l$ & Hbs $\mathrm{Ab}$ \\
\hline BUN & $9-11 \mathrm{mg} / \mathrm{dl}$ & CRP \\
\hline \multirow{3}{*}{\multicolumn{2}{|c|}{$\begin{array}{l}\text { serum creatinine } 0.6 \mathrm{mg} / \mathrm{dl} \\
\text { serum uric acid } 2.8 \mathrm{mg} / \mathrm{dl} \\
\text { serum amylase } 378 \mathrm{IU}\end{array}$}} & $(-)$ \\
\hline & & RAHA \\
\hline & & ANF \\
\hline FBS & $78 \mathrm{mg} / \mathrm{dl}$ & LE test \\
\hline arterial $\mathrm{pH}$ & 7.40 & Wa-R \\
\hline $\mathrm{HCO}_{3}^{-}$ & $22 \mathrm{mEq} / \mathrm{l}$ & 24h Creat. $\mathrm{Cl} 1277 \mathrm{l} /$ day \\
\hline B.E & $-1.1 \mathrm{mEq} / l$ & $\begin{array}{l}\text { PSP test }\left(15^{\prime}\right) 44 \% \\
\text { Fishberg's test } \\
\quad 1.028(\max : 614 \mathrm{mosm} / l)\end{array}$ \\
\hline & & DIP \\
\hline
\end{tabular}

清Ca，Pはおのおの calcium C-test およびdeterminer IP-S (和光純薬Kit) による発色法, 酵素法 によつてそれぞれ測定した。血中C-端iPTHは 
表 2 . Endocrine function before operation.

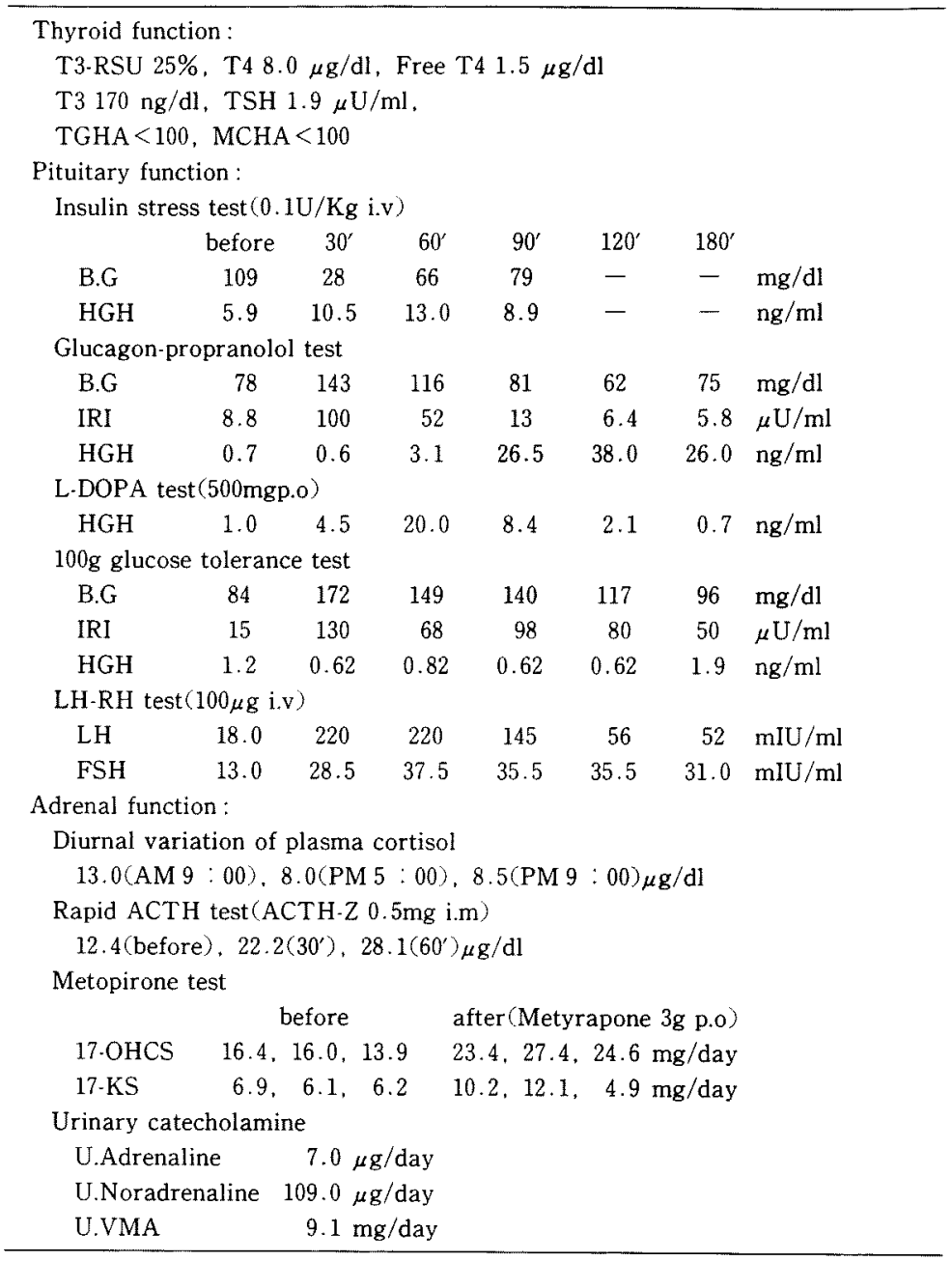

$\mathrm{PTH}$ のCOOH末端基に対する抗体を, $\mathrm{N}$-端 $\mathrm{PPTH}$ は，1，24-h PTHによるN端に対する抗体を用い た栄研イムノケミカル研究所および日本トラベ ノールによる二抗体RIA法にて沶の括の測定し た。层中cyclic-AMPはYamasa cyclic-AMP assay kitにて, 血中vitamin Dの metabolites, 25-hydroxy vitamin $\left.\mathrm{D} 〔 25-(\mathrm{OH})_{2} \mathrm{D}_{3}\right\rfloor$ は competitive protein binding assay, $1,25-(\mathrm{OH})_{2} \mathrm{D}_{3}$ は Yamasaの 1, 25- $(\mathrm{OH})_{2} \mathrm{D}_{3}$ receptor (YSR) を用 いたreceptor assayによつておのおの測定した。

\section{術前後の副甲状腺機能検查（表 3 ）：}

${ }^{75} \mathrm{Se}$-selenomethionine副甲状腺シンチ, 超音波 検查にて明らかな陽性所見を認めなかつたが，血 清Ca，イオン化Ca值および骨性alk-P-aseは常に 異常高值を示した。李た血清i-calcitonin值は正常 であつたが，C-端おさよびN-端iPTHは共に高值で あり, prednisolone $40 \mathrm{mg}$ /日，8 日間投与後も血 清Ca值の有意の低下なく，急速Ca負荷試験 (Goldsmith法)にて尿中P/creatinine比にも有意の変動 を認めなかつた(Fig 5)。また家族性AHOを認め るためウシPTE (parathormone, Eli Lilly Co.) 


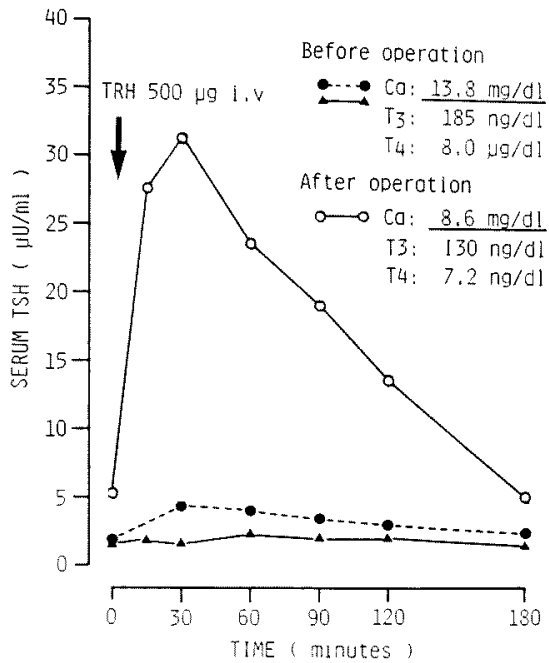

Fig 4. Serum TSH response to TRH before and after surgery.

\section{U和よび合成ヒト1-34PTH (東洋醸造) 100U静 注によるEllsworth-Howard試験を施行した。い ずれの試験でも尿中c-AMP排泄は明らかな增加 を示したが，厍中 $\mathrm{P}$ 排泄の有意の变動は認めなか}

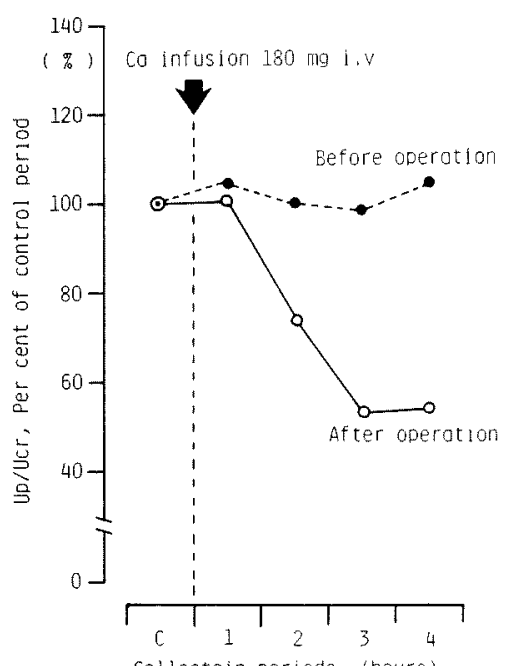

collectoin periods (hours)

Fig 5. Rapid calcium infusion test.

つた (Fig 6A).

以上の成績および他に高C $\mathrm{a}$ 血症の原因となり らる疾患を認め得ないことより，AHOを伴つた $\mathrm{PH}$ と診断したが，自覚症状消失のため，一時外来

表 3. Parathyroid function test.

\begin{tabular}{lccc} 
& before op. & after op. & \\
serum calcium & $11.70 \pm 0.27$ & $8.52 \pm 0.14$ & $\mathrm{mg} / \mathrm{dl}[8.2-10.4]$ \\
& $(9.9-12.3)$ & $(8.6-8.8)$ & \\
serum ionized calcium & 3.25 & 2.09 & $\mathrm{mg} / \mathrm{dl}[2.10-2.35]$ \\
serum phosphate & $2.96 \pm 0.07$ & $4.03 \pm 0.17$ & $\mathrm{mg} / \mathrm{dl}[2.5-4.8]$ \\
& $(2.6-3.3)$ & $(3.5-4.5)$ & \\
serum magnesium & $2.38 \pm 0.04$ & $1.82 \pm 0.02$ & $\mathrm{mg} / \mathrm{dl}[1.2-2.5]$ \\
& $(2.2-2.5)$ & $(1.8-1.9)$ & \\
urinary calcium & $218.0 \pm 44.4$ & $569.9 \pm 71.4$ & $\mathrm{mg} / \mathrm{day}$ \\
urinary phosphate & $476.2 \pm 67.5$ & $100.1 \pm 18.4$ & $\mathrm{mg} / \mathrm{day}$ \\
circulating iPTH & & & \\
c-terminal & $1.54 .1 .6,1.7$ & $0.1,0.3$ & $\mathrm{ng} / \mathrm{ml}[<0.5]$ \\
n-terminal & 0.17 & 0.10 & $\mathrm{ng} / \mathrm{ml}[<0.12]$ \\
circulating i-calcitonin & 100 & 166 & \\
serum 25-(OH ${ }_{2} \mathrm{D}_{3}$ & 12.3 & 7.2 & $\mathrm{ng} / \mathrm{ml}[14-42]$ \\
serum 1,25-(OH) ${ }_{2} \mathrm{D}_{3}$ & 86.5 & $\mathrm{ND}$ & $\mathrm{pg} / \mathrm{ml}[20-60]$ \\
\%TRP & 85.0 & 94.1 & \\
urinary cyclic-AMP & 29.1 & 15.6 & $\mathrm{n} . \mathrm{mole} / \mathrm{mg} \cdot \mathrm{Cr} / \mathrm{h}$ \\
Ellsworth-Howard test & No change of U.p & Increment of both U.P \\
Rapid Ca infusion test & No change of U.p/Cr & Decrement of U.p/Cr \\
db C-AMP infusion & ND & decreased\% $\% R P$ \\
\hline
\end{tabular}

mean $\pm S E,($ ) : range, $[$ ] : normal range

iPTH : immunoreactive parathyroid hormone, ND: not determined 


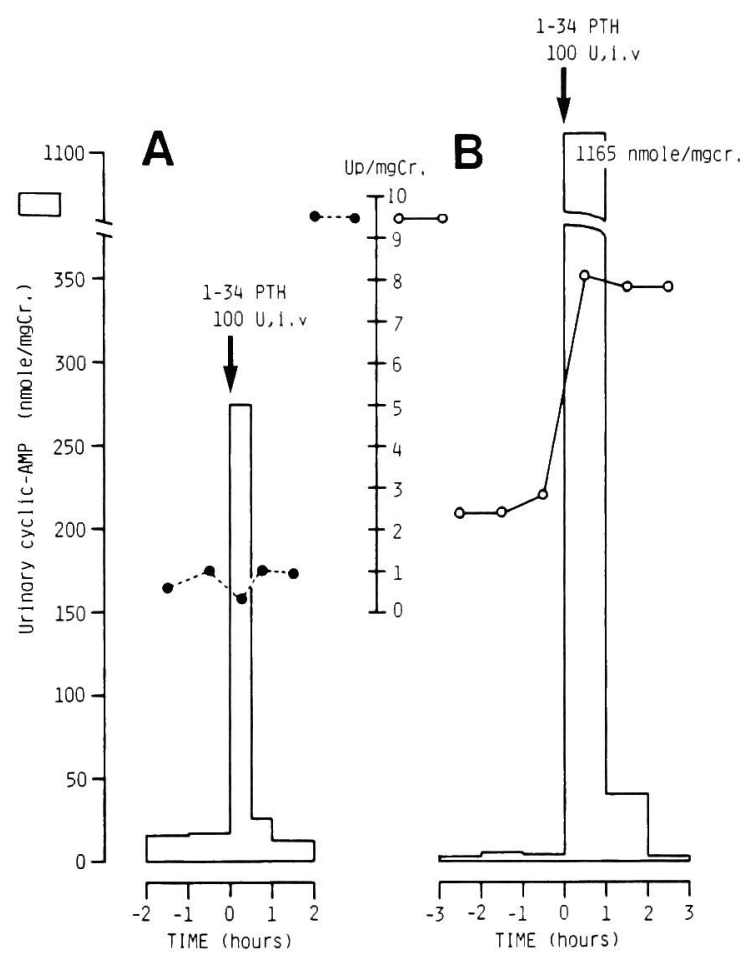

Fig 6. Ellsworth Howard's test before (A) and after surgery (B).

-... \& ०-० : U.P excretion $/ \mathrm{mg} \cdot \mathrm{Cr}$., in preand post-operative state, respectively.

経過観察を行なつた。昭和 57 年夏，再び同様の腹 痛発作に加点，不眠，不気嫌，気分易变性などの 未成熟な性格傾向を伴つた精神症状を呈し，依然 として高Ca血症，血清alk-P-ase高値を認めるこ とより同年 8 月, 別府市野口病院にて手術を施行 した。

甲状腺右葉下極に接する左下部，上皮小体に発 生した一部囊胞形成を伴つた腺腫 $1.5 \mathrm{~g}$ （1.2× $1.0 \times 1.8 \mathrm{~cm})$ を摘出した。他の三個の上皮小体は 萎縮が認められた。病理組織学的検索ではchief cellsを主体とする腺腫であつた（Fig 7).

昭和 58 年 3 月（術後約 7 力月後）に再入院し副 甲状腺機能検査を施行した(表 3 )。術後の経過は Fig 8に示した。血清Ca，P，alk-P-ase扣よび $\mathrm{iPTH}(\mathrm{N}, \mathrm{C}$-端) の正常化に加党，術前体重44.0 $\mathrm{kg}$ より約半年間に $60.8 \mathrm{~kg}$ と急速な増加が認めら

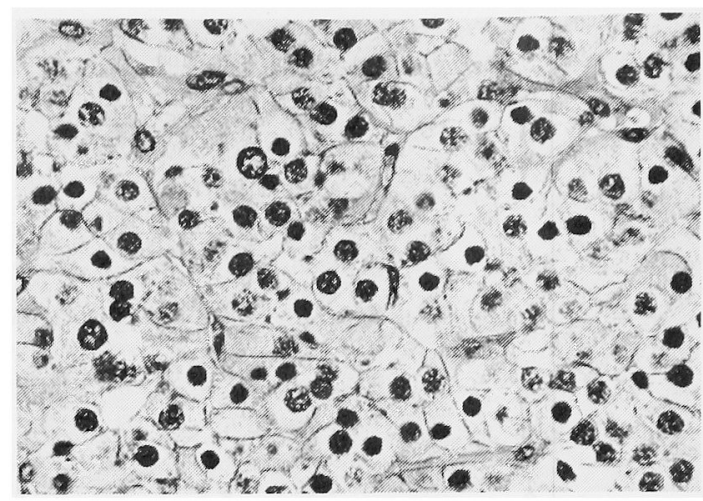

Fig 7. Parathyroid adenoma (chief cell type). H.E stain : $700 \times$.

れた (Fig 3)。急速Ca負荷試験, Ellsworth-Howard試験ではFig 5，6に示すごと々明らかな改善が 認められ，dbc-AMP負荷試験（2.5mg/ $\mathrm{kg}$ を含む 生理的食塩水 $100 \mathrm{ml}, 60$ 分間静注)によつて\% の明らかな低下が認められた（Fig 9)。また赤血 球膜 N蛋白活性 $102.6 \%$ （健常対照 $98.6 \pm 12.0 \%$ ） と異常を認めなかつた。残存上皮小体からのPTH 分泌能を知る目的でEDTA負荷試験 $\left(\mathrm{Na}_{2}\right.$ EDTA $50 \mathrm{mg} / \mathrm{kg}, 60$ 分間点滴)を施行し，負荷前血 清Ca $8.6 \mathrm{mg} / \mathrm{dl}$ 上り点滴終了直後 $6.2 \mathrm{mg} / \mathrm{dl}$ と低 下を示したが，iPTHはN，C-端ともに有意の上昇 は認めなかつた。京た甲状腺機能は $\mathrm{T}_{4} 7.2 \mu \mathrm{g} / \mathrm{dl}$, $\mathrm{T}_{3}$ 130ng/dl, $\mathrm{T}_{3}$-RSU 28.7\%といずれも正常範囲 にあり，TRH試験でもFig 4に示すごとくTSH反 応性にも明らかな改善が認められた。

術後約 1 年後の現在，血清Ca $8.8 \mathrm{mg} / \mathrm{dl}, \mathrm{P} 3.3$ $\mathrm{mg} / \mathrm{dl}$, alk-P-ase $9.3 \mathrm{~K}$-AU, 血清C-端i PTH 0.3 $\mathrm{ng} / \mathrm{ml}$ といずれも正常域にあり,手指しびれ感, テ タニ一症状なく, 消化器症状も消失, 外来にて未 治療のまま経過観察中である。

\section{III. 考案}

本症例は非特異的消化器症状に加之, 副腎皮質 ステロイド抵抗性の高Ca血症，イオン化Caの上 昇, 血中 $\mathrm{N}$-端, C-端iPTHの上昇, 急速 $\mathrm{Ca}$ 負荷試 験の成績, 骨性alk-P-aseの増加なぞを認め, 高Ca 血症の原因となるべき他の疾患を見い出し得ない ことより，いわゆる家族性 $\mathrm{AHOを}$ を伴つた $\mathrm{PH}$ と診 


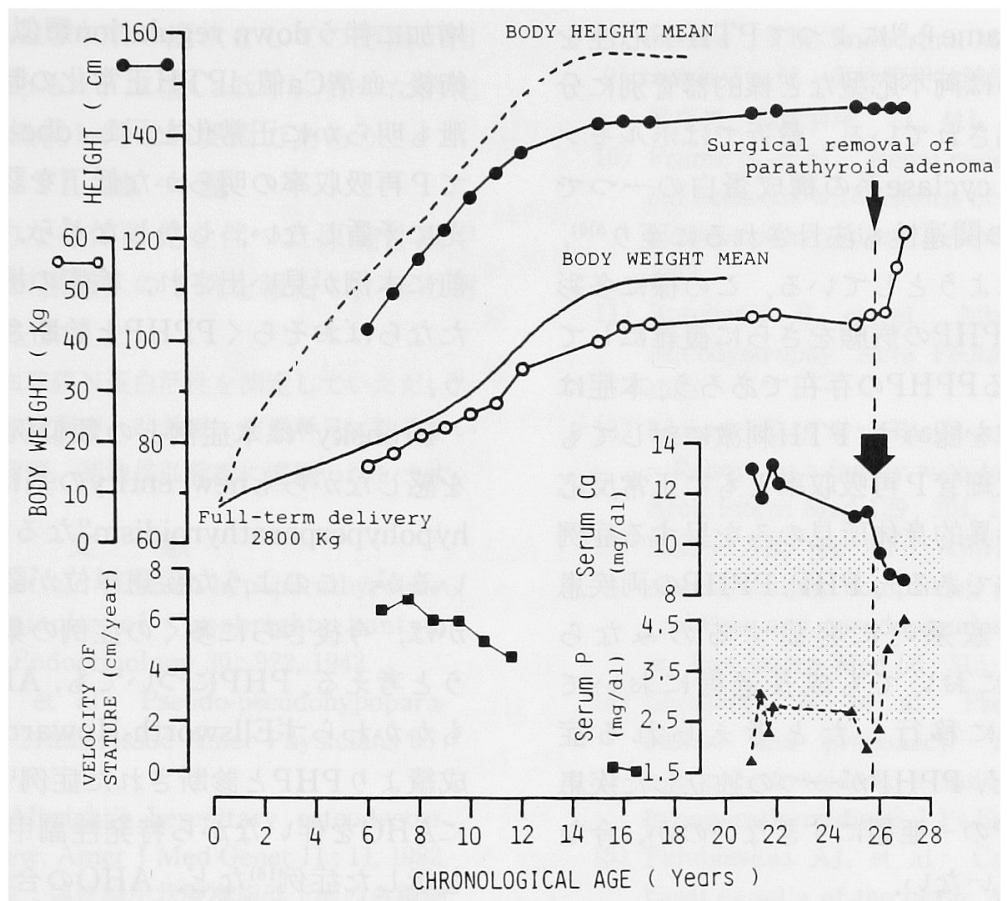

Fig 8. Growth chart and changes of serum calcium and phosphorus before and after surgery.

Note the marked increse in body weight after operation.

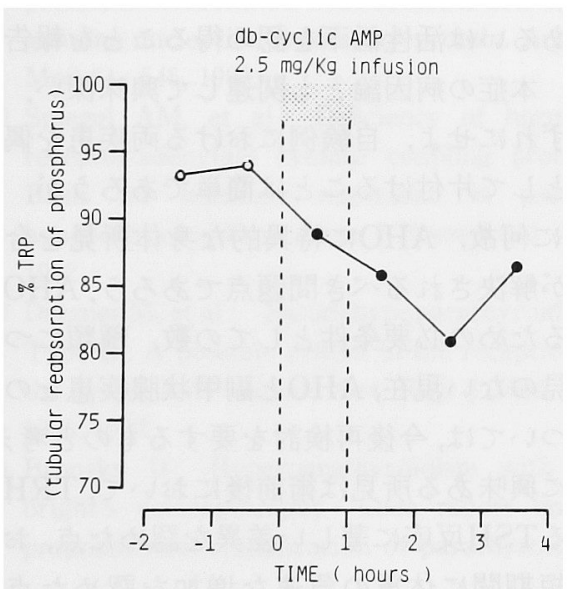

Fig 9. Effect of dibutyryl cyclic-AMP on \%TRP after surgery.

断した。 その後, 高Ca血症に基づく上腹部痛に加 え，精神症状を来すに至り，手術によつて単発性 の副甲状腺腺腫を確認し得た症例である。また染 色体分析, 頭部CTその他の X線所見より, AHO類
似の症候を呈するTurner症候群, Gardner症候 群, Basal cell nevus症候群, 大脳基底核石灰化症 候群などの合併も否定された ${ }^{34499}$

今までにPHにAHOに特徵的身体所見を伴つ た症例の報告は本邦では見い出し得ず，文献上で も1970年, Bronsky ${ }^{8}$ によつて報告された 1 例を認 めるにすぎず，極めてまれな症例と考学られる。

AHOは本来, PHPに随伴する特異な遺伝性身 体骨格奇形であることがAlbright ${ }^{11}$ によつて最初 に指摘された。PHPはPTHに対する生体反応性 の低下によつて特徵づけられる副甲状腺機能低下 症を呈する疾患（群）であるが，近年，その原因 であるPTH不応性の機序が単一でないことが明 らかになり，Ellsworth-Howard試験にて尿中c$\mathrm{AMP}, \mathrm{P}$ 排泄ともに増加を認めない，すなわち $\mathrm{PTH}$ と膜レセプターとの結合，またはATPよりc$\mathrm{AMP}$ 産生の過程に異常があると考えられるPHP I型と, それ以後の過程に異常のあるPHP II型に 


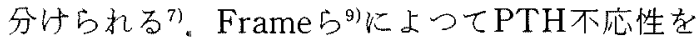
腎型, 骨型あるいは両不応型など標的器管別に分 類することも提唱されている。最近ではホルモン 感受性adenylate cyclase系の構成蛋白の一つで ある“N蛋白”との関連性も注目されるに至り ${ }^{5) 6,}$ さらに細分化されよらとしている。この様に多彩 な病型に加觉て,PHPの病態をさらに複雑にして いる点は, いわゆるPPHPの存在であろう.本症は 血液生化学に異常を認めず, PTH刺激に対しても c-AMP産生能, 尿細管 $\mathrm{P}$ 再吸収率ともk正常反応 を示す, AHOに特異的身体所見のみを呈する症例 につけられた名称である゙ PHP, PPHPの両疾患 はしばしば同一家系内に発症するのみなら ず11 13)，同一例に招いても成長過程に招いて PHPょりPPHPに移行したと考光られる症 例13)ー15)の報告など，PPHPが一つの独立した疾患 であるのか，PHPの一亜型にすぎないのか，今な 扣結論は得られていない。

自験例とPHPとの関連性について考察すると， PHPの副甲状腺組織は時に過形成像を呈するこ とが知られている1他，あるstageに执いては “normocalcemic PHP”なる病態で捕兄られる症 例，さらにosteitis fibrosaなど続発性副甲状腺機 能六進症の所見を示す症例の報告1012116117)などを あわせ考光ると，自験例もある時期，不完全な PHPに基づく低Ca血症が持続し，いわゆるtertiary hyperparathyroidismに類似した病態を捉 し，過形成より自律性を有した腺腫形成へと進展 した可能性も推定しうる。しかしながら,テターー 発作などの既往，皮下あるいは大脳基底核石灰化 など低Ca血症の存在を疑わせる所見括よび組織 学的に過形成を示唆する所見などをる認めなから た点，この考方方では説明困難である。むしろPH に特有の血液生化学所見に加克て, 赤血球膜 $N$ 蛋 白活性低下子認めず, 術前後の各種検査において, adenylate cyclase系をむ含めた標的器管におけ るPTH-receptor系には異常のないことが証明さ れた。術前Ellsworth-Howard試験に打いてDreznerら》の主張するPHP II型に相当する所見が認 められたが,これは高Ca血症の存在, 内因性PTH
増加に伴う down regulation類似の現象であろう。 術後, 血清Ca值, iPTH正常化の時点では尿中 P排 泄子明らかに正常化を示し, dbc-AMP負荷によつ てP再吸収率の明らかな低下を認めた点，この考 亲に矛盾しないしいしながら，もし腺腫発症以 前に本例が見い出され，検索の機会が得られてい、 たならばおそらくPPHPと診断されていたである 5 .

Bronsky ${ }^{8)}$ は本症例との類似例を若干の戸惑い を感じながらも new entityの基に“pseudopseudo hypohyperparathyroidism”なる表題で報告して いるが、このような疾患単位が認められるかどう が, 今後さらに多くの症例の集積が必要であ万 らと考竞る、PHPについても，AHOを伴わないに もかかわらずEllsworth-Howard試験, その他の 成績よりPHPと診断された症例1718)，西るいは逆 にAHOを伴いながら特発性副甲状腺機能低下症 を示した症例18など，AHOの合併はPHPの診断 にとつて必ずしも必発の所見ではなく 両者は概 念上全く別の疾患であるとする考えもある3. こ の点関して，最近Spiegelら5) はAHO非合併例と 異なり, AHOを伴つたPHP I型では全例にN蛋白 欠損あるいは活性低下を認め得ることを報告して おり，本症の病因論とも関連して興味深い。

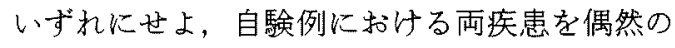
合併として片付けることは簡単であるらが，逆に PHPに何故, AHOK特異的な身体所見を合併し 易いが解決されるべき問題点であろ5.AHOと判 定するための必要条件としての数, 種類について も定見のない現在, $\mathrm{AHO}$ 之副甲状腺疾患との関連 性については，今後再検討を要するものと考える。

他に興味ある所見は術前後において, TRH試験 によるTSH反応に著しい差異を認めた点, 扔よび 術後短期間に体重の急速な増加を認めた点であ る. 前者に関しては, 術前後の末梢甲状腺ホルモ ンレベルに差を認めていないことより，おそらく 血清Ca，イオン化Caの変化に基づく現象である う. 従来より TSH分泌に㧍けるCaイオンの重要 性が知られている他, 最近, 自験例との類似の現

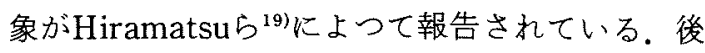


者に関しては, $\mathrm{AHO}$ 本来の症状としての肥满が出 現した可能性もあるが，血清Ca低下に伴つた消化 器症状の消失も無視し得ない要因であるう

\section{VI. 結 語}

AHOK特徵的な身体所見を伴つた原発性副甲 状腺機能立進症（腺腫）の1例を報告し，その病 態について考察を加觉た。

謝辞 本例の赤血球膜N蛋白活性を測定していただいた 自治医科大学内科, 斎藤青一助教授, 病理所見に助言をい たたいた本学第一病理, 菊地昌弘教授に感謝いたします。

\section{文献}

1) Albright $F$, et al: Pseudo-hypoparathyroidis$\mathrm{m}-\mathrm{An}$ example of "seabright bantam syndrome". Endocrinology $30: 922,1942$.

2) Albright F, et al: Pseudo-pseudohypoparathyroidism. Trans Assoc Amer Physicians 65: 337, 1952.

3) Fitch $N$ : Albright's hereditary osteodystrophy : A review. Amer J Med Genet 11:11, 1982.

4) 山本通子, 他：溈性副甲状腺機能低下症の各種病 型および類緑矣患の診断基準。日内分必誌 58 ： 1080, 1982.

5) Levine MA, et al: Resistance to multiple hormones in patients with pseudohypoparathyroidism. Association with deficient activity of guanine nucleotide regulatory protein. Amer J Med 74: 545, 1983.

6) Spiegel AM, et al: Deficiency of hormone receptor-adenylate cyclase coupling protein: Basis for hormone resistance in pseudohypoparathyroidism. Amer J Physiol 243 : E37, 1982.

7) Drezner M, et al: Pseudohypoparathyroidism. Type II : A possible deffect in the reception of the cyclic AMP signal. New Engl J Med 289: 1056, 1973.

8) Bronsky D: Hyperparathyroidism with Albright's osteodystrophy: Case report and a proposed new classification of parathyroidism disease. J Clin Endocrinol Metab 31:271, 1970.

9）山本通子，他：溈性副甲状腺機能低下症とその類 粶疾患。臨床科学 $13: 411 ， 1977$.

10) Frame $B$, et al: Renal resistance to parathyroid hormone with osteitis fibrosa: "Psudohypo. hyperparathyroidism" Amer J Med 52: 311, 1972.

11) Boscherni B, et al: Albright's hereditary osteodystrophy. Acta Pediatr Scand 69: 305, 1980.

12) Kinard RE, et al : Pseudohypoparathyroidism -Report on a family with four affected sisters. Arch Intern Med 129: 204, 1979.

13) Mann JB, et al: Albright's hereditary osteodystrophy comprising pseudohypoparath. yroidism and pseudopseudohypoparathyroidism. Ann Intern Med $56: 315,1962$.

14) Gershberg H, et al: Pseudohypoparathyroidism and pregnancy: Is pseudo-pseudohypoparathyroidism a mild form of pseudo. hypoparathyroidism? J Pediat $56: 383,1960$.

15) Palubinskas AJ, et al: Calcification of the basal ganglia of the brain. Amer J Roentgenol $82: 806,1959$

16) Kidd GS, et al: Skeletal responsiveness in pseudohypoparathyroidism. A spectrum of clinical disease. Amer J Med 68: 772, 1980.

17) Winter JSD, et al: Familiar pseudohypoparathyroidism without somatic anomalies. Cand Med J $123:$ 26, 1980.

18) Daneman D, et al: Hypoparathyroidism and pseudohypoparathyroidism in children. Clin Endocrinol Metab 11:211, 1982.

19) Moses AM, et al: Parathyroid hormone deficiency with Albright's hereditary osteodystrophy. J Clin Endocrinol Metab 39: 496, 1974.

20) Hiramatsu $K$, et al: Thyrotropin secretion in patients with hyperparathyroidism or hypoparathyroidism: Effect of serum calcium on thyrotropin release. J Clin Endocrinol Metab $56: 623,1983$ 